\title{
The Effect of Temperature Stress on Rhizobium trifolii and Sinorhizobium meliloti Strains In Vitro
}

\author{
Monica NISTE, Roxana VIDICAN*, Ioan ROTAR, Rodica POP \\ ${ }^{1}$ University of Agricultural Sciences and Veterinary Medicine, Cluj Napoca, Faculty of Agriculture, \\ Manastur Street, No. 3-5, 400372, Cluj-Napoca, Romania \\ * corresponding author: roxana.vidican@usamvcluj.ro
}

Bulletin USAMV series Agriculture 72(1)/2015

Print ISSN 1843-5246; Electronic ISSN 1843-5386

DOI 10.15835/buasvmcn-agr: 11179

\begin{abstract}
Temperature is often pointed out as the major factor in determining the bacterial community diversity and has a marked influence on survival and persistence of rhizobial stains in soils. Rhizobial strains obtained from different red clover and alfalfa varieties were examined for their ability to survive under different temperature levels on two different media. Rhizobial isolates either increased or remained constant as estimated by plate count at 20 and $35^{\circ} \mathrm{C}$. Significant reduction was detected at $4,10,15$ and $42^{\circ} \mathrm{C}$ in the numbers of CFU for both strains analysed. The differences between the two strains showed that Sinorhizobium meliloti survives better than Rhizobium trifolii to extreme temperatures.
\end{abstract}

Keywords: bacterial strains, stress, temperature.

\section{INTRODUCTION}

Rhizobia are a genetically diverse and physiologically heterogeneous group of symbiotic nitrogen fixing bacteria that form nodules, within the bacteria fix atmospheric nitrogen into ammonia. Temperature is often pointed out as the major factor in determining the bacterial community diversity, and has a marked influence on survival and persistence of rhizobial stains in soils (Abd-Alla et al., 2014). Temperature affects root hair infection, bacteroid differentiation, nodule structure, and the functioning of the legume root nodule. Many studies have shown that sub-optimal temperatures affect the competitiveness of rhizobia for nodulation, delay root infection and inhibit nodule development and nitrogenase activity. In general, rhizobia have a poor growth at temperatures below $10^{\circ} \mathrm{C}$, but they are tolerant to $4^{\circ} \mathrm{C}$ and for most rhizobia, the optimum temperature range for growth in culture is 28 to $31^{\circ} \mathrm{C}$, and many are unable to grow at $37^{\circ} \mathrm{C}$ (Drouin et al., 2000).

\section{AIMS AND OBJECTIVES}

After studying the background of temperature effects on rizobia we proposed to test different isolates obtained from red clover and alfalfa for their ability to grow at different temperature levels.

\section{MATERIALS AND METHODS}

Twenty isolates were identified from colony morphology and gram staining reaction when were cultured on yeast-mannitol agar medium (YEMA). To test the effect of different temperatures $\left(4,10,15,20,25,30,35,40,42^{\circ} \mathrm{C}\right.$ and $28^{\circ} \mathrm{C}$ as control) on rhizobial strains development it was used a medium with yeast extract, mannitol and soil extract and a medium for aerobic $\mathrm{N}_{2}$ fixing microorganisms.

\section{RESULTS AND DISCUSSION}

Rhizobial isolates cultivated on yeast extract medium showed that the number of CFU was low at $4^{\circ} \mathrm{C}$ and at 10 and $15^{\circ} \mathrm{C}$ the differences were 


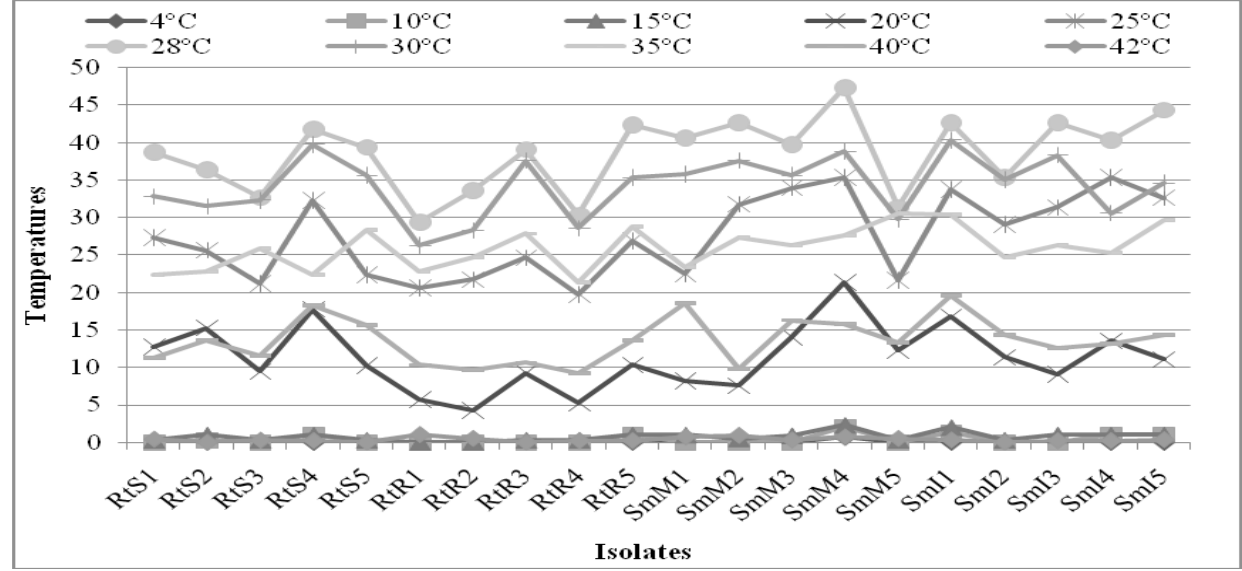

Fig. 1. Rhizobial count $\mathrm{CFU} / \mathrm{mL} \times 10^{7}$ at different temperatures on yeast extract medium

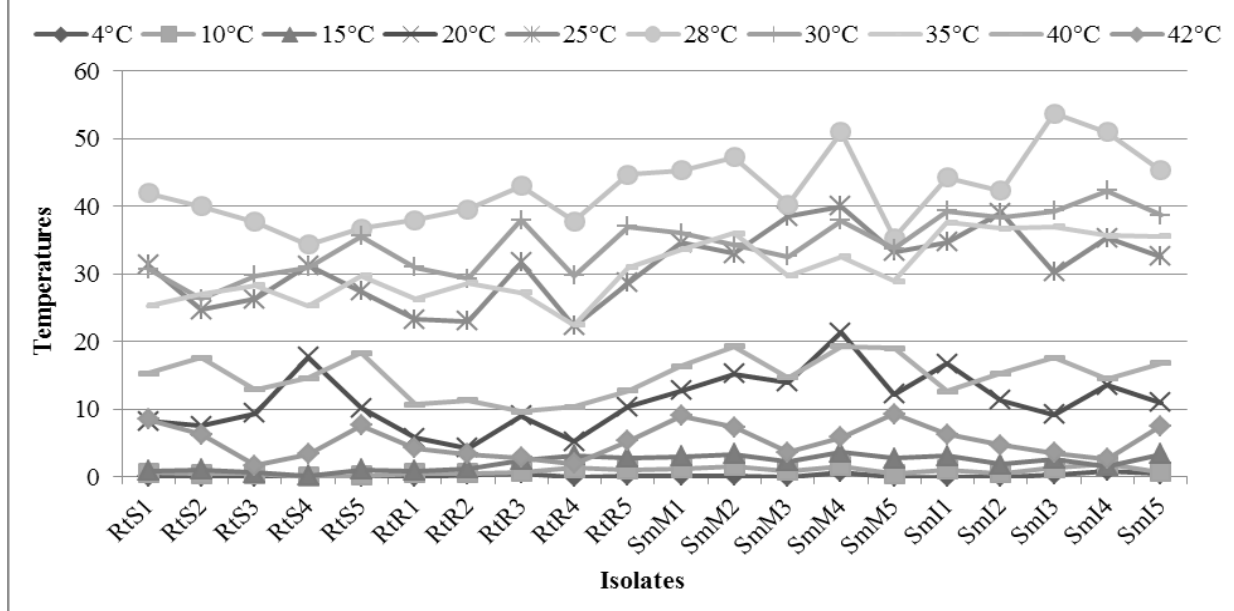

Fig. 2. Rhizobial count $\mathrm{CFU} / \mathrm{mL} \times 10^{7}$ at different temperatures on a medium for aerobic $\mathrm{N}_{2}$ fixing microorganisms

insignificant (Fig. 1). On the second medium used the number of CFU either increased or remained constant as estimated by plate count at 25 and $35^{\circ} \mathrm{C}$. Significant reduction was detected at 4,10 and $15^{\circ} \mathrm{C}$ and $42^{\circ} \mathrm{C}$ in the numbers of CFU for both strains analysed. And as it was expected at $28^{\circ} \mathrm{C}$ on both media the number of CFU was higher. On the medium for aerobic $\mathrm{N}_{2}$ fixing microorganisms the number of colonies was higher for the strains compared to the medium with yeast extract, mannitol and soil extract that could be caused by the complexity of the medium (Fig. 2).

\section{CONCLUSION}

Rhizobium strains differ greatly in their sensibility to high and low temperatures. The differences between the two strains showed that Sinorhizobium meliloti survives better than Rhizobium trifolii to extreme temperatures.

Acknowledgments. This paper was published under the frame of European Social Fund, Human Resources Development Operational Programme 2007-2013, project no. POSDRU/159/1.5/ S/132765.

\section{REFERENCES}

1. Abd-Alla HM, Issa AA, Ohyama T (2014). Advances in Biology and Ecology of Nitrogen fixation, Edition: First, Chapter 7: Impact of harsh Environmental Conditions on Nodule Formation and Dinitrogen Fixation of Legumes., Publisher: InTech, Editors:Takuji Ohyama. pp.131-193.

2. Drouin, P, Prévost D, Antoun H (2000). Physiological adaptation to low temperatures of strains of Rhizobium leguminosarum bv. viciae associated with Lathyrus spp. FEMS Microbiology Ecology. 32:111-120. 